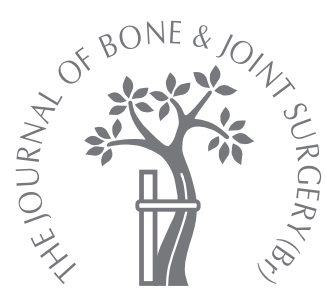

N. R. Howells, H. S. Gill, A. J. Carr, A. J. Price, J. L. Rees

From Nuffield Orthopaedic Centre, Oxford, England

\title{
Transferring simulated arthroscopic skills to the operating theatre
}

\author{
A RANDOMISED BLINDED STUDY
}

N. R. Howells, BSc, MRCS, Research Fellow

H. S. Gill, DPhil, University Lecturer in Orthopaedic Engineering

A. J. Carr, ChM, FRCS Nuffield Professor of

Orthopaedic Surgery

A. J. Price, MA, DPhil,

FRCS(Tr \& Orth), Clinical

Reader in Musculoskeletal

Science and Honorary

Consultant Orthopaedic

Surgeon

J. L. Rees, MD, FRCS(Tr \&

Orth), University Lecturer in

Orthopaedics and Honorary

Consultant Orthopaedic

Surgeon

Nuffield Department of

Orthopaedic Surgery

University of Oxford, Nuffield

Orthopaedic Centre, Oxford

OX3 7LD, UK.

Correspondence should be sent to Mr J. L. Rees; e-mail:

Jonathan.Rees@ndos.ox.ac.uk

C2008 British Editorial Society of Bone and Joint Surgery doi:10.1302/0301-620X.90B4. $20414 \$ 2.00$

$J$ Bone Joint Surg [Br] 2008;90-B:494-9.

Received 31 October 2007:

Accepted 21 December 2007

The aim of this study was to investigate the effect of laboratory-based simulator training on the ability of surgical trainees to perform diagnostic arthroscopy of the knee.

A total of $\mathbf{2 0}$ junior orthopaedic trainees were randomised to receive either a fixed protocol of arthroscopic simulator training on a bench-top knee simulator or no additional training. Motion analysis was used to assess performance objectively. Each trainee then received traditional instruction and demonstrations of diagnostic arthroscopy of the knee in theatre before performing the procedure under the supervision of a blinded consultant trainer. Their performance was assessed using a procedure-based assessment from the Orthopaedic Competence Assessment Project and a five-point global rating assessment scale.

In theatre the simulator-trained group performed significantly better than the untrained group using the Orthopaedic Competence Assessment Project score ( $p=0.0007)$ and assessment by the global rating scale $(p=0.0011)$, demonstrating the transfer of psychomotor skills from simulator training to arthroscopy in the operating theatre. This has implications for the planning of future training curricula.

In the United Kingdom, postgraduate medical training has recently been restructured with the aim of providing a more streamlined approach, focusing on the development of appropriate competencies. Traditionally, in the surgical disciplines an optimum period of 'training time' in the operating theatre has been needed for safe independent consultant practice. Enforced reductions in training and the implementation of restrictions in working hours have led to increasing concerns regarding surgical training. As a result, methods of developing surgical skills away from the operating theatre are being considered. The role of simulation in medical education has recently been recognised, and in general surgery the feasibility, reliability and validity of a variety of simple laboratory-based and virtual reality simulators have been examined. ${ }^{1-7}$ The transferability of the skills acquired in this manner to the operating theatre is termed 'transfer validity'. It has been difficult to demonstrate transfer validity objectively, but encouraging results have been seen in some studies of endoscopic and laparoscopic procedures. ${ }^{8-11}$ In orthopaedics, arthroscopy has become an irreplaceable diagnostic and interventional tool, and its breadth of use is increasing. Some laboratory simulators provide a simple, cost- effective and accessible form of training and have been adopted internationally for many arthroscopic training courses, although the usefulness and validity of such models have not been demonstrated. The aim of this study was to investigate the transfer validity of arthroscopic skills from simulator training to the operating theatre.

\section{Materials and Methods}

Between February 2006 and February 2007, 20 junior orthopaedic trainees were recruited from a single university teaching hospital in the United Kingdom. All prospective participants completed a questionnaire concerning their experience. They had all completed less than two years surgical training and had minimal previous experience of arthroscopy, having observed or assisted in fewer than ten arthroscopies, or other minimal-access procedures.

Using sealed envelopes, they were randomised, either into a group receiving a fixed protocol of simulator training or into a control group that received traditional training in theatre only (Fig. 1).

Simulator training. An arthroscopy knee benchtop simulator (Sawbones, Malmö, Sweden) was set up in a designated skills laboratory. A stan- 


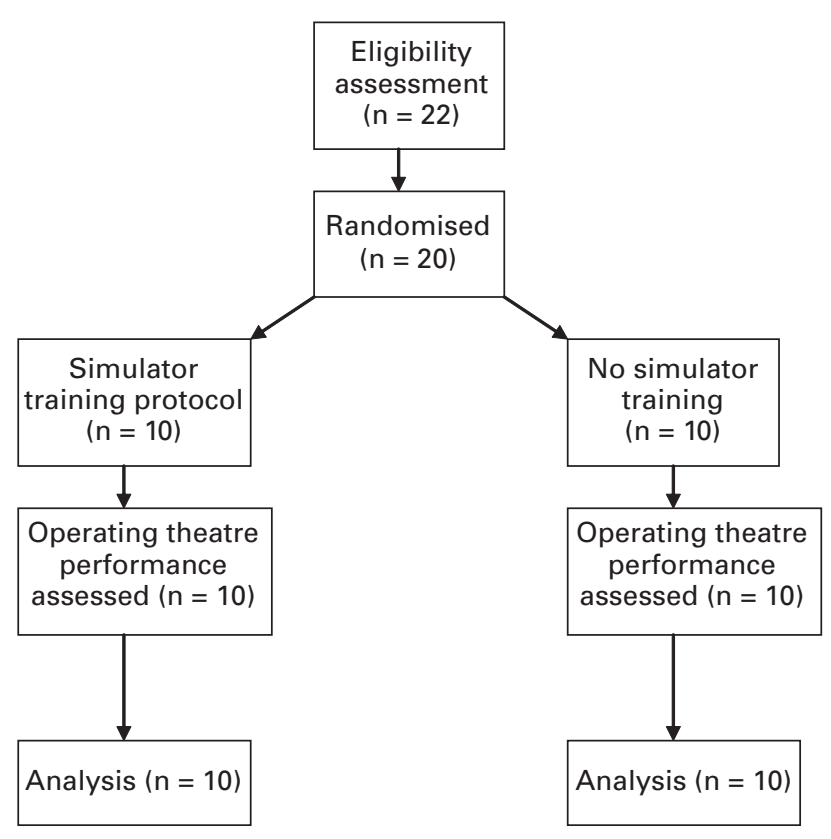

Fig. 1

Flow diagram showing progress of the trainees through the trial.

Table I. Fixed arthroscopic simulator protocol

\begin{aligned} & \hline Diagnostic arthroscopy protocol \\ & \hline 1 Scope and probe inserted \\ & 2 Orientation period: camera position, focus and general 3D \\ & orientation \\ & 3 Enter suprapatellar pouch with knee in extension \\ & 4 Identify trochlea \\ & 5 Identify patella. Visualise all facets \\ & 6 Swing back down medial gutter into medial compartment while \\ & flexing knee \\ & 7 Identify medial femoral condyle \\ & 8 Identify medial tibial plateau \\ & 9 Identify medial meniscus (anterior and posterior horns) \\ & 10 Identify anterior cruciate ligament \\ & 11 Enter lateral compartment following intercondylar notch \\ & 12 Identify lateral femoral condyle, tibial plateau and meniscus \\ & (anterior and posterior horns) \\ & 13 $\begin{array}{l}\text { Come back over into medial compartment again following } \\ \text { intercondylar notch }\end{array} \\ & 14$ Probe articular surface of medial femoral condyle \\ & 15 Probe weight-bearing surface of medial tibial plateau \\ & 16 Probe and lift medial meniscal surface \end{aligned}

dard $30^{\circ}$ arthroscope with an arthroscopic camera and display system (Smith \& Nephew Endoscopy, Huntingdon, United Kingdom) was used for all cases.

The training consisted of three sessions of six simulated arthroscopies during one week. The 18 simulated arthroscopies were supervised by the lead author (NRH)
Table II. Intra-operative technique section of the Orthopaedic Competence Assessment Project arthroscopy procedure-based assessment

\begin{tabular}{|c|c|c|}
\hline & Competencies & $\mathbf{S} / \mathbf{U}^{*}$ \\
\hline 1 & $\begin{array}{l}\text { Follows an agreed, logical sequence or protocol for the } \\
\text { procedure }\end{array}$ & \\
\hline 2 & Consistently handles tissue well with minimal damage & \\
\hline 3 & Appropriate and safe use of instruments & \\
\hline 4 & Proceeds at appropriate pace with economy of movement & \\
\hline 5 & $\begin{array}{l}\text { Deals calmly and effectively with untoward events/ } \\
\text { complications }\end{array}$ & \\
\hline 6 & Uses assistant(s) to the best advantage at all times & \\
\hline 7 & Communicates with scrub nurse clearly and professionally & \\
\hline 8 & $\begin{array}{l}\text { Clearly identifies common abnormalities such as meniscal } \\
\text { and ligamentous tears eg the anatomy of the torn meniscus } \\
\text { using hooks or probes }\end{array}$ & \\
\hline 9 & Protecting the articular surface & \\
\hline
\end{tabular}

and followed a fixed protocol for a diagnostic arthroscopy of the knee agreed by surgeons experienced in this area (AJP, JLR) (Table I).

During simulator training a 3D electromagnetic movement tracking system (Patriot, Polhemus, Colchester, Vermont) was used to assess surgical performance objectively. This tracking technology has been used, and its feasibility, reliability and validity extensively assessed, in laparoscopic and open general surgical procedures, ${ }^{3,4,12}$ and we have recently shown it to be valid as a means of objective assessment of arthroscopic psychomotor skill. ${ }^{13}$ The system consists of two small sensors placed in fixed positions on the dorsum of the hands of the trainee and an emitter which is fixed to the simulator. The output consists of the 3D position ( $x, y, z$ co-ordinates) of each sensor relative to the emitter as a function of time. This output is recorded by a personal computer and processed by custom software (Matlab version 6.5, The MathWorks, Natick, Massachusetts) to produce three outputs, namely the time taken, the total path length and the total number of hand movements. Performance in the operating theatre. All 20 trainees were allocated to a theatre session each. For those trained in the simulator this was always after completion of this experience. In theatre they were all supervised by the same experienced consultant knee surgeon (AJP), who was blinded to their training status. Each trainee was given instruction and then a demonstration of a diagnostic arthroscopy of the knee on one patient. In the next case, the trainee performed the same diagnostic sweep under supervision, which is a common sequence of events as part of their normal training.

The consultant then assessed the performance using the intra-operative technique section of the Orthopaedic Competence Assessment Project procedure-based assessment for diagnostic arthroscopy. The Orthopaedic Competence Assessment Project was developed by the British Orthopaedic Association and the Orthopaedic Specialist Advisory Committee as a framework for specialist training in orthopaedics. Its curric- 
Table III. Global rating scale for intra-operative assessment. Assessment is on a scale of 1 to 5 dependent on the ability of the trainee

\begin{tabular}{|c|c|c|c|c|}
\hline & \multirow[b]{2}{*}{ Skill } & \multicolumn{3}{|l|}{ Score } \\
\hline & & 1 & 3 & 4 \\
\hline 1 & Follows protocol & Unsatisfactory & $\begin{array}{l}\text { Adequate. Occasional } \\
\text { need for guidance and } \\
\text { help }\end{array}$ & $\begin{array}{l}\text { Excellent adherence to agreed } \\
\text { protocol. No prompts. No } \\
\text { mistakes }\end{array}$ \\
\hline 2 & $\begin{array}{l}\text { Handles tissue } \\
\text { well }\end{array}$ & $\begin{array}{l}\text { Careless } \\
\text { Potential to cause } \\
\text { damage }\end{array}$ & $\begin{array}{l}\text { Adequate. No tissue } \\
\text { damage. Occasional } \\
\text { need for increased care }\end{array}$ & $\begin{array}{l}\text { Excellent tissue handling. } \\
\text { Precise and delicate }\end{array}$ \\
\hline 3 & $\begin{array}{l}\text { Appropriate and } \\
\text { safe use of instru- } \\
\text { ments }\end{array}$ & $\begin{array}{l}\text { Dangerous. Risk to patient } \\
\text { and assistant. Potential } \\
\text { for damage to equipment }\end{array}$ & $\begin{array}{l}\text { Adequate use of instru- } \\
\text { ments and scope. Occa- } \\
\text { sional guidance to } \\
\text { ensure instruments } \\
\text { remain within field of } \\
\text { vision }\end{array}$ & $\begin{array}{l}\text { Excellent use of instruments. } \\
\text { Good control of arthroscope. } \\
\text { Instruments constantly within } \\
\text { field of vision }\end{array}$ \\
\hline 4 & $\begin{array}{l}\text { Appropriate pace } \\
\text { with economy of } \\
\text { movement }\end{array}$ & $\begin{array}{l}\text { Erratic pace and move- } \\
\text { ments. Overly rushing or } \\
\text { inappropriately slow }\end{array}$ & $\begin{array}{l}\text { Adequate economy of } \\
\text { movement. Majority of } \\
\text { movements controlled } \\
\text { and careful. Occasional } \\
\text { erratic movement }\end{array}$ & $\begin{array}{l}\text { Excellent fluidity and economy of } \\
\text { movement. Procedure performed } \\
\text { at appropriate pace without } \\
\text { erratic movements }\end{array}$ \\
\hline 5 & $\begin{array}{l}\text { Act calmly and } \\
\text { effectively with } \\
\text { untoward events }\end{array}$ & $\begin{array}{l}\text { Unable to deal with } \\
\text { adverse events. Panic and } \\
\text { inability to respond }\end{array}$ & $\begin{array}{l}\text { Remains calm. Remains } \\
\text { safe. Takes advice from } \\
\text { supervisor. Unable to } \\
\text { cope independently }\end{array}$ & $\begin{array}{l}\text { Excellent ability to cope with } \\
\text { adverse events. Remains calm. } \\
\text { Deals with complication } \\
\text { independently }\end{array}$ \\
\hline 6 & $\begin{array}{l}\text { Appropriate use } \\
\text { of assistant }\end{array}$ & $\begin{array}{l}\text { Fails to involve assistant } \\
\text { appropriately. Resultant } \\
\text { poor positioning. Poor } \\
\text { rapport }\end{array}$ & $\begin{array}{l}\text { Asks for appropriate } \\
\text { joint position at appro- } \\
\text { priate times. Unable to } \\
\text { suggest alternative posi- } \\
\text { tions to improve view/ } \\
\text { access }\end{array}$ & $\begin{array}{l}\text { Excellent use of assistant. Good } \\
\text { rapport. Able to } \\
\text { constantly modify input of } \\
\text { assistant to best advantage } \\
\text { throughout procedure }\end{array}$ \\
\hline 7 & $\begin{array}{l}\text { Communicates } \\
\text { with scrub nurse }\end{array}$ & $\begin{array}{l}\text { Inappropriate communi- } \\
\text { cation resulting in confu- } \\
\text { sion or operative delay }\end{array}$ & $\begin{array}{l}\text { Appropriate communi- } \\
\text { cation with scrub nurse. } \\
\text { Occasional need for clar- } \\
\text { ification from supervisor }\end{array}$ & $\begin{array}{l}\text { Excellent rapport with scrub } \\
\text { nurse. Clear and effective } \\
\text { communication, maximising } \\
\text { procedural efficiency }\end{array}$ \\
\hline 8 & $\begin{array}{l}\text { Clearly identifies } \\
\text { common abnor- } \\
\text { malities }\end{array}$ & $\begin{array}{l}\text { Unable to identify com- } \\
\text { mon abnormalities. } \\
\text { Confusion over basic } \\
\text { anatomy }\end{array}$ & $\begin{array}{l}\text { Adequate identification } \\
\text { of common pathology. } \\
\text { Occasional mistake. } \\
\text { Unsure of precise classi- } \\
\text { fications }\end{array}$ & $\begin{array}{l}\text { Excellent knowlege of } \\
\text { pathology of common } \\
\text { abnormalities. Clear } \\
\text { understanding of classification of } \\
\text { injuries }\end{array}$ \\
\hline 9 & $\begin{array}{l}\text { Protecting the } \\
\text { articular surface }\end{array}$ & $\begin{array}{l}\text { Inability to protect articu- } \\
\text { lar surface appropriately. } \\
\text { Potential to cause } \\
\text { damage }\end{array}$ & $\begin{array}{l}\text { Awareness of need to } \\
\text { protect articular sur- } \\
\text { face. Adequate care } \\
\text { taken. Occasional } \\
\text { prompt from supervisor } \\
\text { required }\end{array}$ & $\begin{array}{l}\text { Excellent awarenes of articular } \\
\text { surfaces. High degree of care } \\
\text { maintained throughout the } \\
\text { procedure }\end{array}$ \\
\hline
\end{tabular}

ulum has been incorporated into the competency-based surgical training structure implemented by the surgical royal colleges in the United Kingdom. ${ }^{14,15}$ Nine of the 14 Orthopaedic Competence Assessment Project criteria for diagnostic arthroscopy were relevant for intra-operative assessment (Table II). For each of these criteria, the trainee is given a score of satisfactory or unsatisfactory.

As the Orthopaedic Competence Assessment Project is a new initiative and has either a satisfactory or an unsatisfactory scoring option, we further quantified performance by using an Objective Structured Assessment of Technical Skill global rating scale, modified to match the same nine Orthopaedic
Competence Assessment Project criteria. Trainees were given a score from one to five for each (Table III). This has been devised by Reznick et $\mathrm{al}^{16}$ and shown to be a valid and reliable means of objective assessment in the operating theatre. It correlates well with movement analysis assessment scores. ${ }^{16,17}$

Statistical analyses. The primary outcome measure was the difference in performance in the operating theatre between the simulator-trained and the untrained groups. The d'Agostini and Pearson omnibus normality test was used to check for normal distribution of data. Data from the untrained group were skewed, and so non-parametric tests were used. 


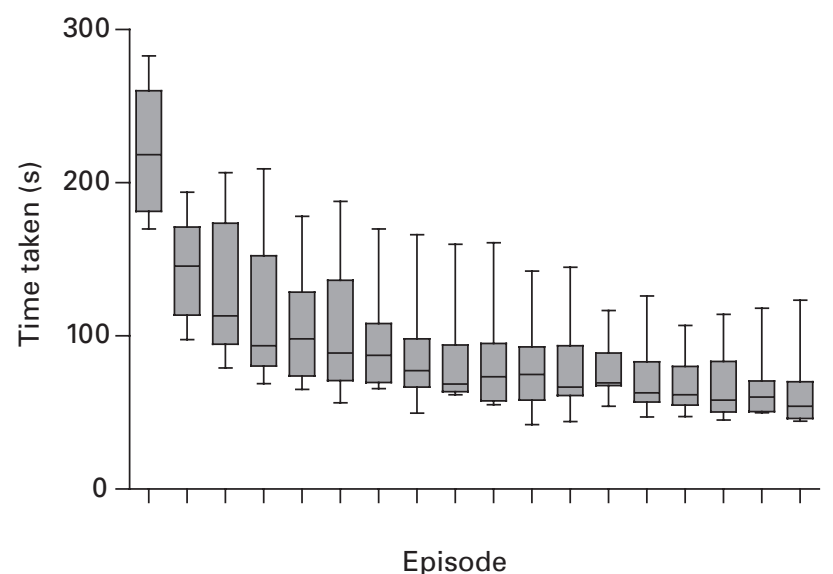

Fig. 2

Graph showing the change in time taken during subsequent training episodes of simulated knee arthroscopy (median, interquartile range, range).

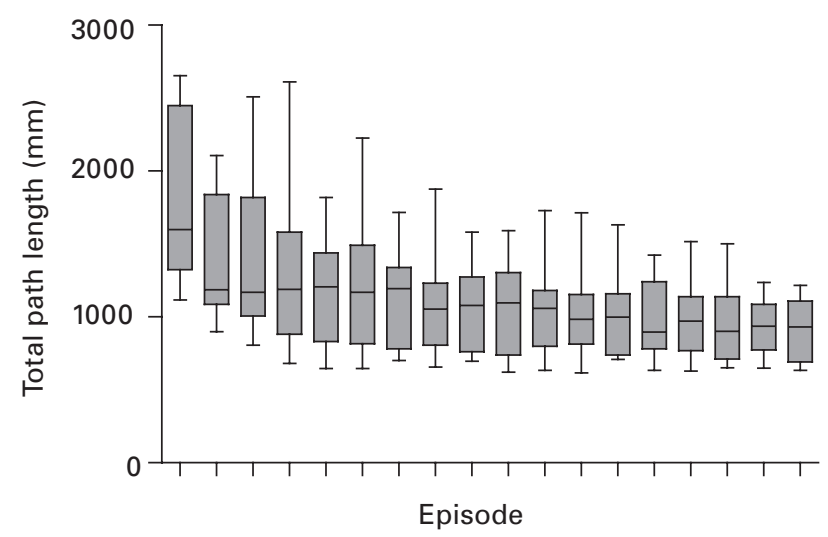

Fig. 3

Graph showing the change in total path length of hand movements during subsequent training episodes of simulated knee arthroscopy (median, interquartile range, range).

Comparison was made between the performance in theatre of the simulator-trained and the untrained group for the proportion of satisfactory scores with the Orthopaedic Competence Assessment Project procedure based assessment and cumulative global rating scale. Analysis was performed using Mann-Whitney U tests.

Further sub-analysis of the simulator-trained group was undertaken to demonstrate objective improvement in simulator performance with training for the movement analysis variables, time taken, total path travelled and total number of hand movements. Mann-Whitney $U$ tests were used to compare the performance before and after training. Statistical analyses were carried out using SPSS (version 12.0, SPSS Inc., Woking, Surrey, United Kingdom).

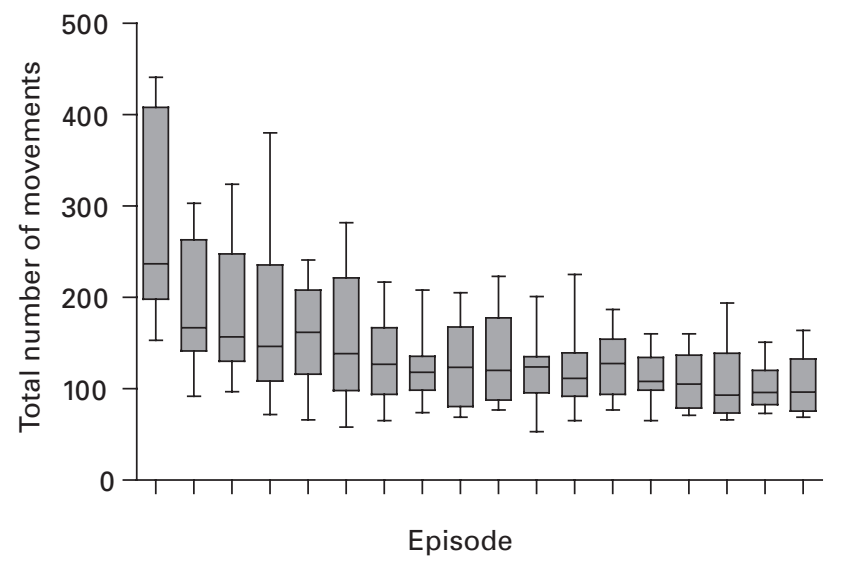

Fig. 4

Graph showing the change in number of hand movements during subsequent training episodes of simulated knee arthroscopy (median, interquartile range, range).

\section{Results}

The groups were equally matched in terms of demographics and previous surgical experience.

Movement analysis showed that the performance of all those in the simulator-trained group improved objectively, with demonstrable learning curves for all three output parameters. The learning curves were all statistically significant, clearly showing improvements in simulator performance and learning during training $(\mathrm{p}=0.001)$ (Figs 2 to 4).

Analysis of the performance in the operating theatre of both groups using the Orthopaedic Competence Assessment Project checklist and the global rating scale showed further differences. The simulator-trained group were seen to significantly outscore the untrained group in terms of both the Orthopaedic Competence Assessment Project $(\mathrm{p}=0.0007)$ and the global rating scores $(\mathrm{p}=0.0011)$ (Figs 5 and 6).

\section{Discussion}

The aviation industry, with similar demands for high levels of technical skill, small margins for error and significant consequences, have been using simulator-based training for decades. ${ }^{18}$ In surgery, simulation as a potential training tool has only recently been considered. It is important to examine its usefulness and validity across the surgical and medical disciplines.

Some transfer validity for simulator training has been shown for laparoscopic cholecystectomy, colonoscopy and endoscopic sinus surgery, ${ }^{8-11}$ and its use will become increasingly common. ${ }^{19}$ The need for specific instruction in arthroscopy for orthopaedic trainees has been identified, ${ }^{20}$ and the current status of simulation has recently 


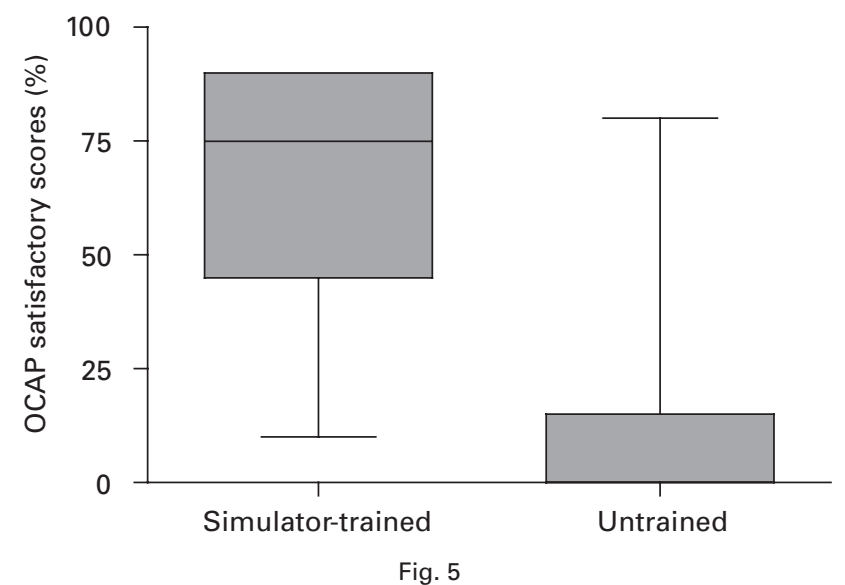

Comparison of proportions of the Orthopaedic Competence Assessment Project (OCAP) satisfactory scores between simulator-trained and non-simulator-trained groups (median, interquartile range, range).

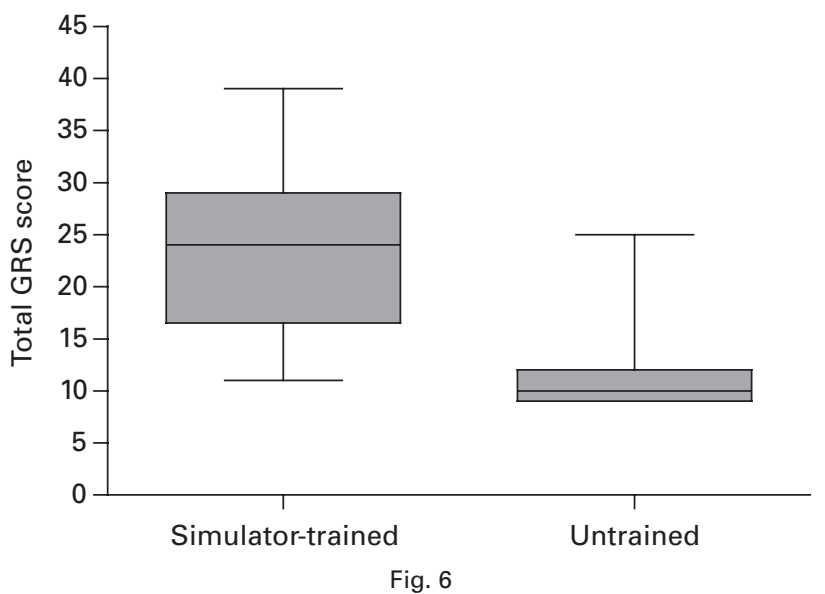

Comparison of global rating scale (GRS) assessment scores between simulator-trained and non-simulator-trained groups (median, interquartile range, range). been reviewed. ${ }^{21}$ The use of simulator training in the development of arthroscopic psychomotor skills has been proposed with little evidence of its usefulness. Laboratory-based simulators are commonly used on arthroscopy skills courses, but there is only anecdotal evidence of subsequent improvement in operative performance and no means of objective assessment has been used. Virtual reality simulators are under development in some centres, ${ }^{22-24}$ but movement analysis has the advantage of providing a simple, reproducible and valid means of assessing technical skill objectively in the simulated environment. Construct validity for the assessment of a variety of open and laparoscopic procedures has been demonstrated, $, 3,4,12$ and our previous experience has demonstrated construct validity for its use in the assessment of arthroscopic skills. ${ }^{13}$ We have now used this to produce objective evidence that training with a bench-top simulator does improve the operative performance of basic arthroscopy.

The main problem with assessment in the operating theatre is its subjectivity, which is the main reason why the Orthopaedic Competence Assessment Project was introduced. It was important to incorporate the Orthopaedic Competence Assessment Project and use its arthroscopy procedure-based assessment as a framework for our assessment because it is now compulsory in orthopaedic training in the United Kingdom, but it has not been subjected to independent testing. Our study, however, was not an attempt to validate the project or its procedure-based assessments. It is not clear whether procedure-based assessment provides a valid method for assessment of competence, but the study does appear to offer some evidence that it can differentiate between trainees of differing ability in its current form.
For this reason we also used an Objective Structured Assessment of Technical Skill model, as it was important to have as objective an assessment as possible. This type of global rating scale has been previously shown to be objective, valid, and to correlate well with movement analysis assessment. ${ }^{16,17}$ Using a global rating scale for each procedure based-assessment made a more objective means of appraisal than the Orthopaedic Competence Assessment Project procedure-based assessment alone. A limitation of our theatre assessment was that trainees were viewed by only one blinded trainer. The presence of two trainers, or a video recording with subsequent analysis by two assessors, would have made the judgement more objective.

Are all trainees amenable to this type of training? In our study, one member of the simulator-trained group performed with substantially worse movement analysis scores than the other nine in the laboratory, but went on to score at the same level as the non-trained group in the operating theatre. This correlates well with previous studies, which have found that despite repeated training there is a proportion of participants who lack sufficient psychomotor skills to perform to the same level as their peers. ${ }^{25}$ However, extremely gifted trainees may have sufficient aptitude to be able to perform simple surgical procedures without the need for prior training. A study with larger sample populations would be required to investigate this further.

This type of training is important in demonstrating technical competence and improvement in surgical and clinical outcomes. A future role would be for trainees to undertake the initial steep part of the learning curve for a procedure in a simulated environment, demonstrate a certain level of simulator competence, and then progress to the operating theatre. The period required for simulator training may vary among trainees. For more experienced surgeons it 
could provide an environment for the development of skills and progression towards new or complex techniques before transfer to the operating theatre.

This study has shown that orthopaedic surgical trainees who have undergone a period of laboratory-based arthroscopic simulator training go on to demonstrate improved technical performance in the operating theatre compared with an untrained group. This transfer validity is of significant importance to those responsible for planning training curricula, and suggests a future role for the incorporation of simulator-based training for procedural skills.

No benefits in any form have been received or will be received from a commercial party related directly or indirectly to the subject of this article.

\section{References}

1. Darzi A, Smith S, Taffinder N. Assessing operative skill: needs to become more objective. BMJ 1999;318:887-8.

2. Reznick RK, MacRae H. Teaching surgical skills: changes in the wind. N Engl J Med 2006;355:2664-9.

3. Datta V, Mackay S, Mandalia M, Darzi A. The use of electromagnetic motion tracking analysis to objectively measure open surgical skill in the laboratory-based model. J Am Coll Surg 2001;193:479-85.

4. Taffinder N, Smith S, Mair J, Russell R, Darzi A. Can a computer measure surgical precision?: reliability, validity and feasibility of ICSAD. Surg Endosc 1999;13(Suppl 1):81.

5. Adrales GL, Chu UB, Witzke DB, et al. Evaluating minimally invasive surgery training using low-cost mechanical simulations. Surg Endosc 2003;17:580-5.

6. Fried GM, Feldman LS, Vassiliou MC, et al. Proving the value of simulation in laparoscopic surgery. Ann Surg 2004;240:518-25.

7. Taffinder N, Sutton C, Fishwick RJ, McManus IC, Darzi A. Validation of virtual reality to teach and assess psychomotor skills in laparoscopic surgery: results from randomised controlled studies using the MIST VR laparoscopic simulator. Stud Health Technol Inform 1998;50:124-30.

8. Grantcharov TP, Kristiansen VB, Bendix J, et al. Randomized clinical trial of virtual reality simulation for laparoscopic skills training. Br J Surg 2004;91:146-50.

9. Seymour NE, Gallagher AG, Roman SA, et al. Virtual reality training improves operating room performance: results of a randomized, double-blinded study. Ann Surg 2002:236:458-63.
10. Edmond CV Jr. Impact of the endoscopic sinus surgical simulator on operating room performance. Laryngoscope 2002;112:1148-58.

11. Sedlack RE, Kolars JC. Computer simulator training enhances the competency of gastroenterology fellows at colonoscopy: results of a pilot study. Am J Gastroenterol 2004;99:33-7.

12. Smith SG, Torkington J, Brown TJ, Taffinder NJ, Darzi A. Motion analysis. Surg Endosc 2002:16:640-5.

13. Howells NR, Brinsden MD, Gill HS, Carr AJ, Rees JL. Motion analysis: a validated method for demonstrating skill levels in arthroscopy. Arthroscopy 2008;in press.

14. No authors listed. Orthopaedic Competence Assessment Project. http:// www.ocap.org.uk (date last accessed 20 May 2007).

15. No authors listed. Intercollegiate Surgical Curriculum Project. http:// www.iscp.ac.uk (date last accessed 20 May 2007).

16. Reznick R, Regeshr G, MacRae H, Martin J, McCulloch W. Testing technical skill via an innovative "bench station" examination. Am J Surg 1997;173:226-30.

17. Datta V, Chang A, Mackay S, Darzi A. The relationship between motion analysis and surgical technical assessments. Am J Surg 2002;184:70-3.

18. Flin R, O'Connor P, Mearns K. Crew resource management: improving team work in high reliability industries. Team Perform Manage 2002;8:68-78.

19. Aggarwal R, Grantcharov T, Moorthy K, Hance J, Darzi A. A competency based virtual reality training curriculum for the acquisition of laparoscopic psychomotor skill. Am J Surg 2006;191:128-33.

20. Sweeney HJ. Teaching arthroscopic surgery at the residency level. Orthop Clin North Am 1982;13:255-61.

21. Michelson JD. Simulation in orthopaedic education: an overview of theory and practice. J Bone Joint Surg [Am] 2006;88-A:1405-11.

22. Heng PA, Cheng $\mathbf{C Y}$, Wong $\Pi$, et al. Virtual reality based system for training on knee arthroscopic surgery. Stud Health Technol Inform 2004;98:130-6.

23. Müller WK, Ziegler R, Bauer A, Soldner EH. Virtual reality in surgical arthroscopic training. J Image Guid Surg 1995;1:288-94.

24. McCarthy AD, Moody L, Waterworth AR, Bickerstaff DR. Passive haptics in a knee arthroscopy simulator: is it valid for core skills training? Clin Orthop 2006;442:13-20.

25. Schijven MP, Jakimowicz J. The learning curve on the Xitact LS 500 laparoscopy simulator: profiles of performance. Surg Endosc 2004:18:121-7. 